\title{
Innovation in Elementary Schools: Engaging Augmented Reality and Balinese Folklore for Science Learning Aids
}

\author{
Putu Nanci Riastini ${ }^{1,2, *}$, Ni Made Sriwijnyani ${ }^{3}$, IGP Suryadarma $^{1}$, Muhammad Nur Wangid ${ }^{1}$ \\ ${ }^{1}$ Science Education Program, Graduate School, Yogyakarta State University, Yogyakarta, 55281, Indonesia \\ ${ }^{2}$ Primary Teacher Education Program, Ganesha University of Education, Singaraja, Bali, 81116, Indonesia \\ ${ }^{3} 29$ Dangin Puri Elementary School, Denpasar, Bali, 80234, Indonesia
}

Received August 16, 2020; Revised October 23, 2020; Accepted November 1, 2020

\section{Cite This Paper in the following Citation Styles}

(a): [1] Putu Nanci Riastini, Ni Made Sriwijnyani, IGP Suryadarma, Muhammad Nur Wangid, "Innovation in Elementary Schools: Engaging Augmented Reality and Balinese Folklore for Science Learning Aids, "Universal Journal of Educational Research, Vol. 8, No. 12, pp. 6552-6560, 2020. DOI: 10.13189/ujer.2020.081220.

(b): Putu Nanci Riastini, Ni Made Sriwijnyani, IGP Suryadarma, Muhammad Nur Wangid (2020). Innovation in Elementary Schools: Engaging Augmented Reality and Balinese Folklore for Science Learning Aids. Universal Journal of Educational Research, 8(12), 6552-6560. DOI: 10.13189/ujer.2020.081220.

Copyright $\bigcirc 2020$ by authors, all rights reserved. Authors agree that this article remains permanently open access under the terms of the Creative Commons Attribution License 4.0 International License

\begin{abstract}
This study aimed at developing an application for elementary science education that uses Augmented Reality to integrate culture (folklore) and science knowledge. The application was called SABAR (that stands for Satua Bali (Balinese folklore)-Augmented Reality). It was developed by using the ADDIE model. The analysis stage was carried out by a FGD. At the design stage, SABAR blueprint was prepared, science concepts related to the selected folklore were mapped, the content was drafted, and the initial draft was prepared. At the development stage content validation, practitioners consultation, and feasibility testing were carried out. The results of expert judgment were then analyzed using Aiken's validity index. Then a questionnaire was distributed to 10 elementary school teachers and 100 elementary school students from Denpasar City. The implementation stage was carried out in one-shot case study. The try-out involved one class with 30 students, namely the fifth grade of Public Elementary School No 29 Dangin Puri, Denpasar. The variable tested was scientific literacy. The data were analyzed using one-sample t-test. The final stage was evaluation. The result of the content validity test showed that SABAR has high validity coefficient. The responses of the practitioners and students showed that SABAR is easy to use, attractive, and helps students in learning. The analysis of one-sample test showed that $\mathrm{p}$-value $=0.000$. In other words, there is a
\end{abstract}

difference in the elementary school students' scientific literacy when they learned science by using the application. This study needs to be continued with a wider range of population.

Keywords Augmented Reality, Balinese Folklore, Elementary School, Science Learning Aids

\section{Introduction}

The $21^{\text {st }}$ century obliges students to have various competencies to support their lives. The term competency can be defined as the ability of an organism to interact effectively toward its environment that includes the integration of knowledge, manner and attitude, and also skills [1-3]. One of the skills required is science and technology literacy. It cannot be denied that these skills have become one of the primary needs and life style nowadays. By acquiring the skills, students will be able to fulfill the demands of the employment requirements [4]. The acquisition of the skills may happen if teachers apply the constructivist approach in the classroom [5]. For example, teachers may involve mobile technology in learning in order to provide the students with meaningful learning experiences. Augmented Reality (AR) becomes 
one of the most interesting and interactive mobile technologies, because of its ability to present realities with 3D (three-dimension) objects in real time [6]. In short, the involvement of mobile technology as a learning aid will help students to develop their $21^{\text {st }}$ skills.

Another competency that is considered important is cultural literacy. Culture includes values, norms, knowledge, beliefs, thoughts, cultural heritages in the form of artifacts and objects, practice, experience, places, as well as languages $[7,8]$. Referring to the theories of Culturally Responsive/ Relevant Education and Cultural-Historical-Activity, the culture of the students' acts as a learning foundation and as a bridge that connects academic or scientific knowledge, the students' culture, and the environment [8-11]. This approach helps all students a) to acquire more knowledge about cultural diversity, b) to utilize the cultural heritages, experiences, and perspectives which are varied in terms of ethnicity as the source of learning, in order to enhance their chance to learn and to improve their learning achievements [10]. For example, Balinese folklore, which is well known as Satua Bali, can be integrated into science contents. One of them is I Buta Teken I Lumpuh (A Blind Man and A Paralyzed Man) that can be related to the five senses (eyesight) and human skeleton as well as diseases related to them $[12,13]$. Therefore, ethno-pedagogy can help students to understand and find the relevance of science to themselves [14], while developing their cultural literacy.

In contrast, an engagement of ethno-pedagogy and mobile technology simultaneously in science education to develop the $21^{\text {st }}$ century skills has not yet been attempted. This is true in all levels of education, including elementary education. Teachers adopt a teacher-centered instruction mostly (59.17\%) and rarely use technology (100\%) [15]. The most likely cause of this is the unavailability of products that integrate mobile technology and local culture in one package. Another likely reason is that teachers still do not know much and do not have enough skill about how to relate the local culture (local genius) and mobile technology to learning contents in one time. Thus, teachers have never related Balinese folklore to elementary school science contents, due to the lack of understanding and the skill [13]. The condition is worsened by the fact that the students are not familiar with Balinese folklore, so that the teachers do not see any potentiality of Balinese folklore for science education. It might happen because of the influx of various modern stories which are presented by using most recent technology that automatically replace the role of folklore for them [16]. Meanwhile, Satua Bali is told verbally and has become more rarely told by the parents. Hence, by integrating science contents and Balinese folklore by using mobile technology one can have a very important aid for learning to help teachers develop the $21^{\text {st }}$ century skills of the students, especially scientific literacy and cultural literacy.

Augmented Reality (AR) can be considered as the exact application of mobile technology to place Balinese folklore and science contents in a digital platform. The combination of them into an aid for learning will result in an interactive digital media for science education in elementary school. The learning aid which is further called SABAR application stands for Satua Bali-Augmented Reality. SABAR application has some advantages. First, the use of Augmented Reality makes 'SABAR' able to present real objects in $3 \mathrm{D}$ in real time when the users do the scan marker $[17,18]$. The presence of science contents in the form of real objects helps students to learn science contextually according to the stage of child mental development (concrete operational phase) [19]. Second, SABAR application is implemented with Android-based mobile phones and offline. AR can be implemented by using a device like computer, mobile gadget, and so on [20]. Mobile learning allows students to learn through portable devices at flexible times and places, and motivates them to achieve their goals [21-23]. This advantage helps both teachers and students because mobile phones are owned by and are so familiar with children from almost all socio-economic backgrounds, thus it is not difficult to have one. Likewise, the internet connection problem can be solved easily. Third, the 'SABAR' application can help teachers to create effective learning experiences, especially in scientific literacy, technological literacy and cultural literacy. It means that students can learn science in accordance with their culture rather than other cultures, so that they will have meaningful learning experience [24]. Fourth, SABAR application can help the intergenerational cultural inheritance, so that Satua Bali can still exist in the community. Based on those advantages, SABAR application is extremely needed to develop the $21^{\text {st }}$ century skills. Thus, the purpose of the study was to develop the SABAR application as a science learning aid in elementary school.

\section{Materials and Methods}

The study was in the form of research and development. This study was conducted at public elementary schools in Denpasar City, Bali, Indonesia. The development model which had been implemented was ADDIE model. ADDIE model consists of five steps, namely analysis, design, development, implementation, and evaluation [25-28]. The research procedures, participants, and data analysis based on the five steps of ADDIE can be described as follows.

\subsection{Analysis}

At the early stage, the students' learning characteristics, competencies, and learning environment were analyzed first [29]. In order to collect early data, focus group discussion (FGD) was conducted. The FGD involved 10 elementary school teachers in Denpasar, Bali, Indonesia. 
The FGD was conducted in 90 minutes. The questions were asked by the leader of the discussion. The questions were related to the elementary students' learning characteristics in Denpasar City, the teaching and learning process that is commonly followed by the teachers for science contents, skills that the teachers and the students have already had, the skills that become the targets to be developed in the teachers and students, their needs to achieve the skill targets, and the elementary school learning environment in the region. The FGD participants expressed their opinions based on the leader's questions. The participants' questions in the discussion activity were recorded in detail. The data that were obtained and the FGD activity were then analyzed.

Interactive descriptive analysis was used to analyze the results of the discussion. This analysis was done by reading several times the discussion record to get an understanding of the data. The meaning units were then summed up, by finding the similarities and differences. The units with the same meanings were grouped under one theme.

\subsection{Design}

The purpose of this stage was to design the prototype of SABAR and its initial production. SABAR application can be explained as an aid for learning in elementary school science education that integrates science contents and Balinese folklore aided with Augmented Reality. The inter-relations between science contents and the contents of Balinese folklore become the contents of the SABAR application. The supporting contents of the SABAR application contents are Balinese moral values and cultural values that are related to the main contents. Augmented Reality is a digital technology that presents the contents as realities with 3 dimensions.

At the initial design stage, marker book and Android based Application were produced. At the first phase in the design stage, the SABAR application blue print was designed. The blue print contains the description components of marker book, AR application, and SABAR real time display. At the second phase, the types of Balinese folklore that are related to science contents were mapped. In addition, at this phase moral values and local wisdoms that are related to science contents were mapped too. The marker book scenario and the 3D display were designed at the third phase. The scenario design contained pictures, texts on marker book, animation displays, narration voice, back sounds, and students' assignments at the last page of the book. A scenario was made for each picture in marker book. The last phase was the production of the application based on the scenarios that had been written. The production process involved 3D unity application and Vuforia.

\subsection{Development}

At the development stage, experts' validation and practitioners' response to SABAR application were the main concerns. The content validation of the SABAR application was judged by experts and their agreement was shown with a rating scale. Two experts were involved, one of them was a technology expert and another one an elementary education expert. The assessment components consisted of three different aspects. The aspects were content, construction, and delivery. In the content aspect, the compatibility between the content and science curriculum in elementary school, the depth of content, and the suitability of the content with the elementary school students' developmental stage were the basic things to assess. In the construction aspect, an assessment was done to find the suitability of the product to the product characteristics and literature that underline the product, and stimulation to the learning process of the students. In delivery, the product was assessed in terms of its ease of use, functioning, language and symbols, as well as the attractiveness of presentation. The result of the validation was analyzed using Aiken's validity index and had been used as a consideration in revising the product.

Furthermore, the product had also been consulted to practitioners for having more inputs and suggestions. There were three elementary school teachers involved in this process. The teachers answered questions in an open-question questionnaire. The questions were about the ease in using the product, failure possibility, the attractiveness, completeness and clarity of the presentation, level of language and symbols used, and also the stimulation toward students' learning activities. Inputs and suggestions were used as the considerations for a further revision.

The feasibility of the products is based on comments given by the teachers and the students. The feasibility of the product based on the teachers' comments is concerned with the ease of use, attractiveness of the product, efficiency of time, clarity of the contents, the suitability with the users' characteristics, and the problems in using the product. Meanwhile, the feasibility based on the students' comments was about the ease of use, the completeness and clarity of the contents, the ease to understand the contents, and the product ability to assist the students in learning. The data for the feasibility were collected through questionnaire in which teachers and students were the source of the data. The respondents had used the application in the teaching and learning process in a classroom before. They were then asked to answer questions in the feasibility questionnaire.

There were 10 teachers of $5^{\text {th }}$ grade of elementary school and 100 students from 10 different public elementary schools in Denpasar city involved in the feasibility testing. The city of Denpasar was chosen based on three considerations. First, the city of Denpasar is the center of government in Bali Province and is also considered as a city of education in Bali. So, the city becomes the model for other cities. Second, the 
development of technology in this city can be considered to be well-developed. It means there are no obstacles in using gadgets, the internet connection, and other supporting technologies. Third, there is a high variety in demographic and socio-cultural backgrounds of the teachers and the students.

\subsection{Implementation}

The product was tested with the fifth grade students of the Public Elementary School No. 29 Dangin Puri, Denpasar, Bali. The school is situated in the center of the city. The fifth grade teacher was a government worker with 10 years working experience. She was a holder of a professional certificate as an elementary school teacher. The fifth class consisted of 30 students. Their ages were between 10 and 11 . The teacher and the students of the fifth grade were familiar with smart phones but had never used SABAR application or other applications like it. It means that SABAR application was a new application to them. All of the fifth grade students were used as the pre-experimental sample.

The try-out design that was used was a pre-experimental design, that is, one-shot case study design. The variable for the product testing was scientific literacy of the students. Scientific literacy is an understanding of scientific knowledge and problem solving skills based on scientific concepts [30]. The components of scientific literacy selected were conceptual and procedural scientific literacies. The choice of the components was based on the correspondence with the SABAR contents. The data collected were then arranged based on the components chosen. The data on scientific literacy were collected with a test. The test used the multiple choice format with four options. The test consisted of 10 questions. Since the test had the multiple choice format, the score of each answer was 1-0. The data were analyzed by one sample t-test. Before the test was tested with one sample-t-test, normality testing was performed first.

\subsection{Evaluation}

The evaluation stage was actually conducted in every development process. However, the last process of evaluation was focused on the goals attainment and the targeted result. The result of the evaluation was then used as the product final revision.

\section{Results and Discussion}

The result of this study was SABAR application, which can be defined as an aid in learning science for elementary schools that have specific characteristics. The product was developed through several processes. The result from every single process can be described below.

\subsection{Analysis Result in Early Stage}

A focus group discussion was held by involving 10 elementary school teachers to gain data on the early stage. The data were in the form of students' learning characteristics, students' competencies, and their learning environment. The result showed that the students were excited to learn when the learning process used mobile phones. By using mobile phones in the learning process, there are several skills that can be stimulated, like collaborative activity that helps much in group work, increases the students' creativity, and enhances their communication skills [31,32]. The students were also good at using mobile phones due to their daily habit of using them at home. Mobile phones which were used by students were Android based smart phones with various specifications.

In relation to Satua Bali that was integrated to the science contents, the teachers stated that they had never done that. So, the students had not any experiences of learning science through their local culture. This happened due to the unavailability of aids for learning science that are compatible with the specification needed. The students were familiar with studying science from the materials that are based on books, with pictures or videos as additional media. In order to provide students with meaningful learning, teachers are demanded to be able to cross the line of their science culture and their own culture by connecting the students' prior knowledge to their science knowledge [24]. For that reason, the teachers hoped to have aids for learning which could integrate Satua Bali and science contents in the form of a new attractive technology.

\subsection{SABAR Design}

SABAR application has two main components, namely marker book and Android based Application. AR requires a platform called augmented book which is equipped with Quick Response Code (QRC) marker and AR application for handheld device $[33,34]$. Both of the components were developed based on the design that had been prepared previously. In the design stage, the activities that had been done were drafting the blue print of SABAR application, mapping the Satua Bali that are related to the fifth grade of elementary school science contents and the issues in the community in Bali, drafting the scenario of marker book and 3D appearance, as well as creating an initial product.

The first phase was designing blueprint of SABAR application as guidelines in producing the product. The characteristics of SABAR application that were described in the blueprint can be seen on table 1 . 
Table 1. Blueprint Of 'SABAR'

\begin{tabular}{|l|l|l|}
\hline \multicolumn{1}{|c|}{ Aspects } & \multicolumn{1}{|c|}{ Satua Bali } & \multicolumn{1}{c|}{ Description } \\
\hline \multirow{2}{*}{ AR } & a. Marker book of 'SABAR' & $\begin{array}{l}\text { Containing 2D (two-dimension) pictures of Satua Bali } \\
\text { and storyline texts. } \\
\text { Quick Response Code (QRC) marker } \\
\text { Showing home works at the last page that involve the } \\
\text { students' parents }\end{array}$ \\
\cline { 2 - 3 } & b. AR Application & $\begin{array}{l}\text { Android based Application } \\
\text { Camera scanner marker }\end{array}$ \\
\cline { 2 - 4 } & c. Real Time Display & $\begin{array}{l}\text { Displaying 3D objects } \\
\text { Displaying voice narration about science topics that had } \\
\text { been integrated with Satua Bali } \\
\text { Presenting issues among societies and ethno science based } \\
\text { on the topics } \\
\text { Presenting moral values }\end{array}$ \\
\hline
\end{tabular}

Table 2. Content Mapping Of 'SABAR'

\begin{tabular}{|c|c|c|c|}
\hline Satua Bali tittle & Science Topics & Issues & Moral Values \\
\hline $\begin{array}{l}\text { Pedanda Baka (A } \\
\text { Greedy Pastor) }\end{array}$ & $\begin{array}{l}\text { Vertebrate and invertebrate animals } \\
\text { Animals' apparatus }\end{array}$ & $\begin{array}{l}\text { Kokokan birds (White Stork) conservation } \\
\text { in Gianyar, Bali }\end{array}$ & $\begin{array}{l}\text { Cautiousness, } \\
\text { solidarity, honesty }\end{array}$ \\
\hline $\begin{array}{l}\text { Siap Selem (A Black } \\
\text { Hen) }\end{array}$ & $\begin{array}{l}\text { Animals' breeding } \\
\text { (Oviparous, Viviparous, Ovoviviparous) } \\
\text { Types of animals based on foods } \\
\text { (Carnivore, Herbivore, Omnivore) } \\
\text { Ecosystem and its components }\end{array}$ & $\begin{array}{l}\text { Cats which are considered holy animal } \\
\text { Tabuh Rah } \\
\text { (Balinese cock fighting tradition) }\end{array}$ & Sincerity, greedy \\
\hline $\begin{array}{l}\text { I Buta Teken I } \\
\text { Lumpuh (A Blind } \\
\text { Man and A Paralyzed } \\
\text { Man) }\end{array}$ & $\begin{array}{l}\text { Human skeletal system } \\
\text { Abnormalities on human skeletal system } \\
\text { How to prevent from abnormalities on } \\
\text { human skeletal system } \\
\text { Five senses }\end{array}$ & $\begin{array}{l}\text { Funeral procession of physically } \\
\text { handicapped in Trunyan Village, } \\
\text { Kintamani, Bangli District, Bali Province. }\end{array}$ & $\begin{array}{l}\text { Gratitude, sense } \\
\text { of helpfulness, } \\
\text { toughness }\end{array}$ \\
\hline
\end{tabular}

The second phase was designing the mapping process of Satua Bali that was related to science contents, especially for the fifth grade of elementary school, moral values, and issues in Balinese community that are related to the topics. There were three Satua Bali that had been chosen to be integrated with the science contents. The tittles of them were Pedanda Baka, Siap Selem, and I Buta Teken I Lumpuh. The complete mapping can be seen on table 2.

The third phase was designing the scenario of marker book and 3D display. Example of content scenarios of SABAR application can be seen in Figure 1.

Page 1
Marker Picture: A blind man and a palsied man sat side by side in a
rickety hut.
Text: In a village, there lived two brothers. They were poor and had no
parents. His brother is blind, while his younger brother is palsied. They
can't work, so they often don't eat.
Animation: A blind man sits side by side with a palsied man in a rickety
but. The palsied man touches his feet. Around the hut, tall grass swayed
by the wind.
Back sound: sad atmosphere
Audio narration: Palsy is a temporary or permanent loss of the ability
to move the muscles of the body. It can occur due to birth, accidents,
stroke, polio virus attack, injury, and others. Palsy from birth can be
caused due to disnuption in the development process of the baby in the
womb, infection, brain growth disorders, premature birth, or difficult
delivery.

Figure 1. Example of Content Scenario SABAR
The initial products were produced based on those scenarios. The examples of the initial products of marker book and 3D displays can be seen in Figures 2 and 3.

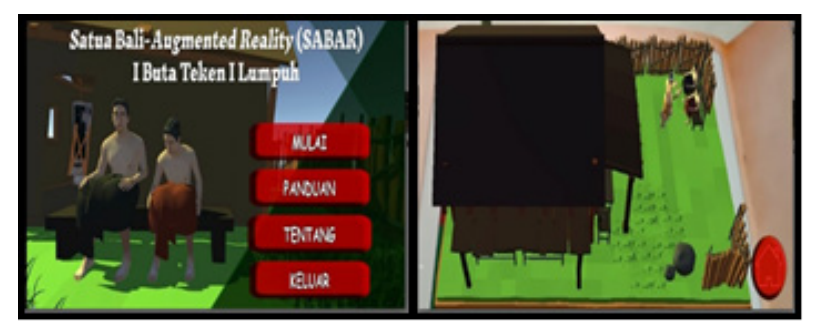

Figure 2. Example of Marker Book

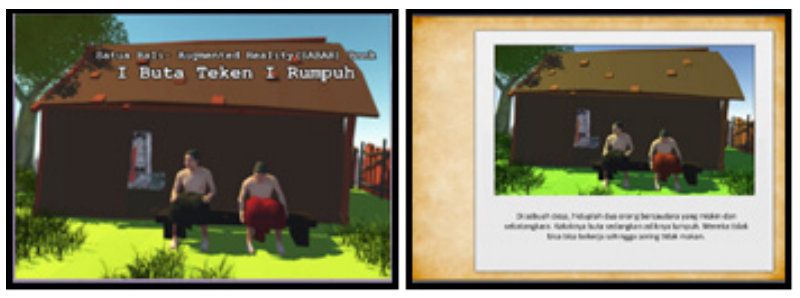

Figure 3. Display Example on Android Based Application

\subsection{Development Stage Result}

The product validation of SABAR involved two experts. The results of the validation by both experts were shown in a rating scale which was analyzed with Aiken's validation index. The result showed that the three products of SABAR (Pedanda Baka, Siap Selem, and I Buta Teken I Lumpuh) 
had high values of validity, with validity coefficient above 0.8 . If the validity coefficient is $\geq 0.80$, it means that the validation values can be considered high [35]. Experts' comments on the three products of SABAR were about the attractiveness of the content due to the connection between the academic knowledge and local cultural heritage. Moreover, they also contained issues in the community and moral values in narration. Narration reading was also interesting, because it was told just like story telling that made it suitable for learning characteristics of elementary school's students. Somehow, there was an obstacle on 3D object's rotation in order to be able to be seen from all angles. Based on the inputs from the experts, revising process on the products had been done.

The revised version then had been consulted to three elementary school teachers as practitioners. Those three practitioners stated that SABAR application was easy to use and interesting. It contains science knowledge that is connected with local cultures, issues in the communities, as well as moral values. Material presentation is complete and clear, its language is easy to understand, and it is able to stimulate the students to study more than other media. However, this application requires mobile phones with compatible specifications, which become a potential cause of failure of the product. Then, the practitioners gave suggestions to reduce the size and memory consumption of the application, in order to be compatible with all types and specifications of students' mobile phones. Thus, based on those practitioners' suggestions, the product had been back to the revision process.

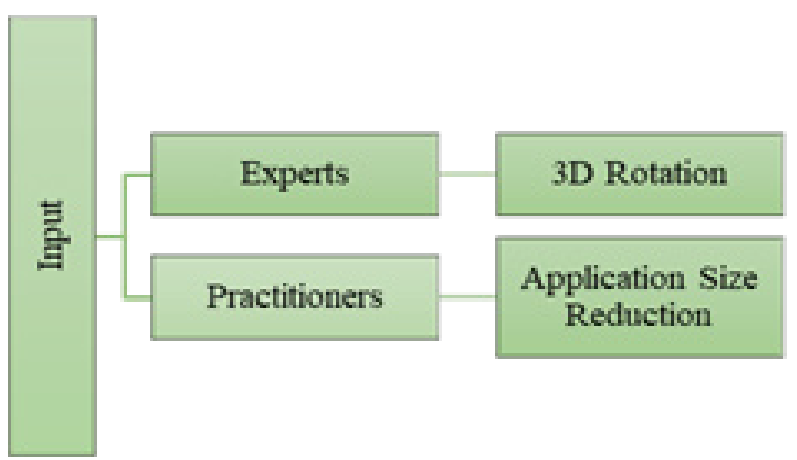

Figure 4. Inputs and Suggestions from Experts and Practitioners on Development Stage

A try-out process was carried out to know the feasibility and the effect of SABAR application. One of the try-out activities is shown in Figure 5.
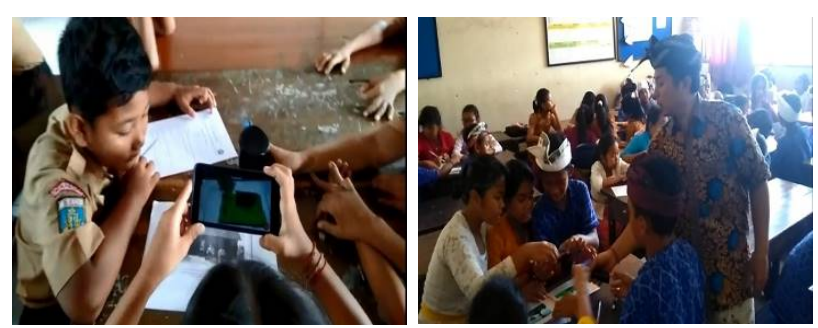

Figure 5. Try Out Activity in $5^{\text {th }}$ Grade of Elementary School's Students
Based on the teachers' comments, the product feasibility can be seen from several points, like ease of use, attractiveness, time efficiency, and user compliance, which can be seen in Figure 6.

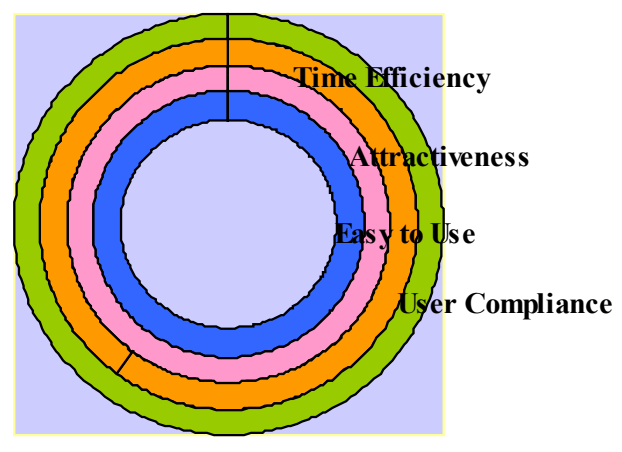

Figure 6. Feasibility (\%) based on Teachers' Comments

Referring to the figure above, it can be stated that $100 \%$ teachers stated that the product was easy to use, interesting, and suitable for use with elementary school students. In relation to the time efficiency in using the product, $40 \%$ of the teachers stated that the products were very effective and efficient; meanwhile the rest of them stated that it was quite efficient. AR is a complement to the traditional teaching media which can give teachers opportunity to create a learning process through various activities in the classroom, to integrate various contents [33], to create learning based on discovery, and facilitate the teaching and learning process [36,37]. Yet, in order to be able to install SABAR application, it requires certain specifications of Android-based mobile phones. Teachers also suggested that more Satua Bali could be added to the application and could be downloaded at Play Store.

The product feasibility based on the students' comments showed that $100 \%$ of the students agreed that 'SABAR' application was easy to use, very helpful in learning process, complete in content, clear, and easy to understand. Students said that they were happy to study using SABAR application and hoped that the application could be downloaded from Play Store. So, the students were able to interact, the learning process could be done anywhere in a collaborative way, involving students themselves, visualized abstract objects, and creating a bridge between formal and informal learning.

\subsection{Implementation of 'SABAR'}

The product testing involved 30 pupils of $5^{\text {th }}$ grade of 29 Dangin Puri Elementary school in Denpasar city. This process was carried out to determine the effect of SABAR application on the students' scientific literacy. The data of the students' scientific literacy met the criteria of normal distribution, as seen on Table 3 . 
Table 3. Result of Normality Test

\begin{tabular}{|c|c|c|c|c|c|c|}
\hline \multicolumn{3}{|c|}{ Tests of Normality } \\
\hline & \multicolumn{3}{|c|}{ Shapiro-Wilk } \\
\cline { 2 - 7 } & Statistic & df & Sig. & Statistic & df & Sig. \\
\hline PK & .141 & 30 & .135 & .941 & 30 & .096 \\
\hline
\end{tabular}

Table 4. Result of One Sample T-Test

\begin{tabular}{|c|c|c|c|c|c|c|}
\hline \multicolumn{7}{|c|}{ Sample Test } \\
\hline & \multicolumn{9}{|c|}{ Test Value $=30$} \\
\cline { 2 - 6 } & $\mathrm{t}$ & $\mathrm{df}$ & Sig. (2-tailed) & Mean Difference & \multicolumn{2}{|c|}{$95 \%$ Confidence Interval of the Difference } \\
\cline { 5 - 7 } & & & .000 & 35.000 & Lower & Upper \\
\hline PK & 9.606 & 29 & & 27.55 & 42.45 \\
\hline
\end{tabular}

The result of one sample t-test showed that $t$ value was 9.606 higher than the $\mathrm{t}$ table $(\mathrm{t}$ table $=2.045)$. Furthermore, $\mathrm{p}$ value was 0.000 , lower than 0.05 . In short, the students' scientific literacy will be different if they use SABAR application. Ethno-pedagogy in science education helps the students to understand scientific concepts and enhance their problem solving skill [15]. Ethno-pedagogy also helps the students to learn more easily since it is suitable with their cultural background [38]. Likewise, the use of mobile technology helps teachers to implement a good way of teaching to enhance the students' HOTS $[39,40]$. The result of one sample T-test can be seen on table 4 .

\subsection{Final Revision}

The last stage was the final revision. The inputs from the teachers' and students were used as the final revision material. The applications have also been uploaded in Play Store, with the name after the application name.

\section{Conclusions}

'SABAR' application is an aid in learning science for elementary school students which integrates science contents, Satua Bali (Balinese folklore), and Augmented Reality. This aid has two components, namely marker book and Android based application. Marker book contains 2D pictures of Satua Bali, QRC marker, and assignments for students which give chance to parents to be involved. The application can be installed in Android based mobile phones. If the camera scanner is activated, it will display $3 \mathrm{D}$ objects with narration audio related to the science topics, Satua Bali' contents, moral values, and issues in the communities. Based on Aiken's validity index, the product has a high validity value. The practitioners' response showed that the technology is easy to use, interesting, complete in its presentation, clear, and easy to understand. Moreover, the teachers' comments were like the Practitioners' about the product feasibility. Based on the students' review, as users, SABAR application is easy to use, complete, clear, easy to understand the content, and helpful in learning. Based on one sample t-test analysis, the $\mathrm{t}$ value was 9.606 higher than the $\mathrm{t}$ table $(\mathrm{t}$ table $=2.045)$. Furthermore, $\mathrm{p}$ value was 0.000 , lower than 0.05 . This means that the students' scientific literacy would be different if they had used 'SABAR' application. On the other hand, an effectiveness testing of 'SABAR' application for enhancing students' scientific literacy achievements in larger population has not yet been done. So has not the effectiveness testing of the application for enhancing other $21^{\text {st }}$ century skills. These limitations become critical issues for further research. It is hoped that policy makers can encourage and financially support research that is related to the topic of integration of local culture, science contents and educational technology.

\section{Acknowledgments}

This study had gotten considerable support from Raka Wira and the team.

\section{REFERENCES}

[1] White, R. W, "Motivation Reconsidered: The Concept Of Competence," Psychological Review, vol 66., no 5., pp 297333, 1959. https://doi.org/https://doi.org/http://dx.doi.org/10.1037/h00 40934

[2] Kaendler, C., Wiedmann, M., Rummel, N., \& Spada, H, "Teacher Competencies for the Implementation of Collaborative Learning in the Classroom : a Framework and Research Review," Educational Psychology Review, vol 27., pp 505-536., 2014. https:// doi.org/10.1007/s10648-014-928 8-9

[3] Zhu, C., Wang, D., Cai, Y., \& Engels, N, "What core competencies are related to teachers' innovative teaching?," 
Asia-Pacific Journal of Teacher Education, vol 41., no 1., pp 9-27, 2013. https://doi.org/10.1080/1359866X.2012.753984

[4] Ananiadou, K., \& Claro, M, "21st century skills and competences for new millennium learners in OECD countries," OECD Education Working Papers, vol 41., no 33., 2009. https://doi.org/10.1787/218525261154

[5] Duran, M., \& Dökme, I, "The effect of the inquiry-based learning approach on student's critical-thinking skills," Eurasia Journal of Mathematics, Science and Technology Education, vol. 12., no 12., pp 2887-2908, 2016. https://doi.org/10.12973/eurasia.2016.02311a

[6] Perez-Lopez, D., \& Contero, M, "Delivering Educational Multimedia Contents through an Augmented Reality Application: A Case Study on its Impact on Knowledge Acquisition and Retention," TOJET: The Turkish Online Journal of Educational Technology, vol. 12., no 4, pp 19-28, 2013.

http://search.proquest.com/docview/1492503411?accountid $=14887$

[7] Isayeva, O, "Modeling Cultural Competence in Teaching Humanities to Medical Students," American Journal of Educational Research, vol. 2., no 12., pp 51-55, 2014. https://doi.org/10.12691/education-2-12B-10

[8] Kana'iaupuni, S., Ledward, B., \& Jensen, U, "Culture-Based Education and Its Relationship to Student Outcomes," Kamehameha Schools, Research \& Evaluation, 2010. http://citeseerx.ist.psu.edu/viewdoc/download?doi=10.1.1.4 54.50\&rep=rep1\&type $=$ pdf

[9] Carlone, H. B., Johnson, A., \& Eisenhart, M, "Cultural Perspectives in Science Education,". In Handbook of Research on Science Education, Vol. II, 2014, pp 651-670. https://www.taylorfrancis.com/books/e/9781136221972/cha pters/10.4324/9780203097267-43

[10] Gay, G, "Teaching To and Through Cultural Diversity," Curriculum Inquiry, vol 43., no 1., pp 48-70, 2013. https://doi.org/10.1111/curi.12002

[11] Huda, M. E, "Cultural Model of Classroom Instruction for ELT in Bangladesh," International Journal of English Linguistics, vol 3., no 1., pp 67-74, 2013. https://doi.org/10.5539/ijel.v3n1p67

[12] Margunayasa, I. G., \& Riastini, P. N, "The Character Value in " Satua Bali " and Its Application of Teaching in Elementary Schools," The 1st International Conference on Elementary School Teacher Education (ICESTE), 2015, pp $2-6$.

http://research.unissula.ac.id/file/publikasi/211315026/8563P ublikasi_ICESTE_UNJ_2015.pdf

[13] Riastini, P. N., Widowati, A., Ratnasari, Y., \& Suryadarma, I, "Enganging Balinese Culture and Technology in Digital Era : A Review to Foster Primary Teachers' Competencies," 6th International Conference on Educational Research and Innovation (ICERI 2018), 2019, 244-248., https://doi.org/https://doi.org/10.2991/iceri-18.2019.50

[14] Rahmawati, Y., Ridwan, A., Cahyana, U., \& Wuryaningsih, $\mathrm{T}$, "The integration of ethnopedagogy in science learning to improve student engagement and cultural awareness," Universal Journal of Educational Research, vol 8., no 2., pp 662-671, 2020. https://doi.org/10.13189/ujer.2020.080239
[15] Sumardi, L., Rohman, A., \& Wahyudiati, D, "Does the teaching and learning process in primary schools correspond to the characteristics of the 21st century learning?," International Journal of Instruction, vol 13., no 3., pp 357 370, 2020. https://doi.org/10.29333/iji.2020.13325a

[16] Bakhir, N. M., Bidin, M. O., Amirul, A., \& Abdul, B, "Preserving and Promoting Malay Folklores and Legends Using Interactive Motion Comic: The Fang King (Raja Bersiong)," SHS Web Conf, 2018., https://doi.org/https://do i.org/10.1051/shsconf/20184507001

[17] Cuendet, S., Bonnard, Q., Do-lenh, S., \& Dillenbourg, P, "Designing augmented reality for the classroom," Computers \& Education, vol. 68., pp 557-569, 2013. https://doi.org/10.1016/j.compedu.2013.02.015

[18] Fernandez, M, "Augmented Virtual Reality: How to Improve Education Systems," High. Learn. Res. Commun. Higher Learning Research Communications, vol. 7., no 71., pp 1-15, 2017. https://doi.org/10.18870/hlrc.v7i1.373

[19] Koocher, G. P, "Childhood, Death, and Cognitive Development," Developmental Psychology, vol. 9., no 3., pp 369-375, 1973. https://doi.org/10.1037/h0034917

[20] Johnson, L. F., Levine, A., Smith, R. S., \& Haywood, K, "Key Emerging Technologies for Postsecondary Education," Tech Directions, vol. 70., no 4., 2010. https://eric.ed.gov/?id=EJ916644

[21] Aboraya, W. A., \& Elkot, M. A, "The Effect Of A Flipped Learning Pedagogical Model Enhanced With A Mobile Application On Students' Performance And Motivation," International Journal of Scientific \& Technology Research, vol 9., no 07., pp 50-56, 2020. www.ijstr.org

[22] Santoso, H. B., Hakim, M. L., Nursalamah, R. K., \& Putra, P. O. H, "Development of Mobile Self-Monitoring Tool Prototype Based on User-Centered Design," International Journal of Emerging Technologies in Learning, no 14., no 24., pp 42-55, 2019. https://doi.org/10.3991/ijet.v14i24.120 43

[23] Wirjawan, J. V.D., Pratama, D., Pratidhina, E., Wijaya, A., Untung, B., \& Herwinarso, "Development of smartphone app as media to learn impulse-momentum topics for high school students," International Journal of Instruction, vol 13., no 3., pp 17-30, 2020.https://doi.org/10.29333/iji.2020.133 $2 \mathrm{a}$

[24] Appanna, S. D, "Embedding Indigenous Perspectives in Teaching School Science," The Australian Journal of Indigenous Education, vol. 40., pp 18-22, 2011. https://doi.org/10.1375/ajie.40.18

[25] Kuswanto, "Development Of Micro Economic Theory Teaching Materials With ADDIE Model Approaches," International Journal Of Scientific \& Technology Research, vol 9., no 6., pp 383-387, 2020. https://www.ijstr.org/../De velopment-Of-Micro-Economic-Theory-TeachingMaterials-With-Addie-Model-Approaches.pdf

[26] Muruganantham, G, "Developing of E-content package by using ADDIE model," International Journal of Applied Research, vol. 1., no 3., pp 52-54, 2015. https://www.researchgate.net/profile/Muruganantham_Gan esan/publication/339102976_Developing_of_E-content_pc akge by using_ADDIE_Model/links/5e3d6c4392851c7f7f $249 \mathrm{dc} 8 /$ Developing-of-E-content-pcakge-by-using-ADDIE- 
Model.pdf

[27] Reinbold, S, "Using the ADDIE Model in Designing Library Instruction," Medical Reference Services Quarterly, vol 32., no 3., pp 244-256, 2013. https://doi.org/10.1080/02763869. 2013.806859

[28] Salas-Rueda, R.-A., Salas-Rueda, É.-P., \& Salas-Rueda, R.-D, "Analysis and Design of the Web Game on Descriptive Statistics through the ADDIE Model, Data Science and Machine Learning," International Journal of Education in Mathematics, Science and Technology, vol. 8., no 3., pp 245-260, 2020. https://doi.org/10.46328/ijemst.v8i 3.759

[29] Suartama, I. K., Setyosari, P., \& Ulfa, S, "Development of an Instructional Design Model for Mobile Blended Learning in Higher Education," International Journal of Emerging Technologies in Learning, vol. 14., no 16., pp 4-22, 2019. https://doi.org/https://doi.org/10.3991/ijet.v14i16.10633

[30] Ogunkola, B. J, "Scientific Literacy: Conceptual Overview, Importance and Strategies for Improvement," Journal of Educational and Social Research, vol. 3., no 1., pp 265-274, 2013. https://doi.org/10.5901/jesr.2013.v3n1p265

[31] Sandberg, J., Maris, M., \& De Geus, K, "Mobile English learning: An evidence-based study with fifth graders," Computers and Education, vol. 57., no 1., pp 1334-1347, 2011. https://doi.org/10.1016/j.compedu.2011.01.015

[32] Uzunboylu, H., \& Ozdamli, F, "Teacher perception for m-learning: Scale development and teachers' perceptions," Journal of Computer Assisted Learning, vol 27., no 6., pp 544-556, 2011. https://doi.org/10.1111/j.1365-2729.2011.0 0415.x

[33] Billinghurst, M., \& Duenser, A, "Augmented Reality in the Classroom," Computer, vol. 45., no 7., pp 56-63, 2012. https://doi.org/10.1109/MC.2012.111
[34] Darmawiguna, I. G. M., Sunarya, I. M. G., Kesiman, M. W. A., Arthana, K. R., \& Crisnapati, P. N, "The Augmented Reality Story Book Project: A Collection of Balinese Miths and Legends," In 3D Physics Virtual Laboratory as a Teaching Platform, vol. 9254., Springer, 2015, pp. 71-88., https://doi.org/10.1007/978-3-319-22888-4

[35] Retnawati, H, "Analisis Kuantitatif Instrumen Penelitian (Panduan Peneliti, Mahasiswa, dan Psikometrian)," Parama Publishing, 2016.

[36] Chiang, T. H. C., Yang, S. J. H., \& Hwang, G. J, “Students' online interactive patterns in augmented reality-based inquiry activities," Computers and Education, vol. 78., pp 97-108, 2014. https://doi.org/10.1016/j.compedu.2014.05.0 06

[37] Yuen, S. C.-Y., Yaoyuneyong, G., \& Johnson, E, "Augmented Reality: An Overview and Five Directions for AR in Education," Journal of Educational Technology Development and Exchange, vol. 4., no 1., pp 119-140, 2011. https://doi.org/10.18785/jetde.0401.10

[38] Rasna, I. W., \& Tantra, D. K, "The Local Wisdom in Bahasa Indonesia Text Books in a Low Class: Ethno-Pedagogy Study," International Journal of Linguistics, Literature and Culture, vol. 3., no 1., pp 117-125, 2017. https://doi.org/10.21744/ijllc.v3i1.523

[39] Mokhtar, M. M., \& Jamil, M, "Mobile technology usage: The shift of focus to cultivate high level thinking skills (HOTS) in the Malay language education system," Universal Journal of Educational Research, vol 8., no 1A., pp 156-163, 2020. https://doi.org/10.13189/ujer.2020.0813 20

[40] Yilmaz, R. M., \& Goktas, Y, “ Using augmented reality technology in storytelling activities: examining elementary students' narrative skill and creativity," Virtual Reality, vol 21., no 2., pp 75-89, 2017. https://doi.org/10.1007/s10055016-0300-1 